\title{
eHealth solutions to fight against COVID-19: A scoping review of applications
}

\author{
Parisa Eslami ${ }^{1}$, Sharareh R. Niakan Kalhori ${ }^{1}$, Moloud Taheriyan ${ }^{1 *}$ (1)
}

Received: 30 Jul 2020

Published: 1 Apr 2021

\section{Abstract}

Background: eHealth has a notable potential to help in prevention, diagnosis, treatment, screening, management, and control of the COVID-19 pandemic. Since ehealth is considered here broadly, as an umbrella term, it also covers subsets like telehealth and mhealth This study aimed to review the literature to identify and classify subdomains of eHealth solutions that have been utilized, developed, or suggested for the COVID-19 pandemic.

Methods: A comprehensive literature search was performed using the PubMed, Scopus, Embase, and Cochrane library databases in April 2020, with no time limitation. The search strategy was built based on 2 concept domains of eHealth solutions and covid-19. For each concept domain, the search query comprised a combination of free text keywords identified from reference papers and controlled vocabulary terms. Obtained results were classified, graphically presented, and discussed.

Results: Of the 423 studies identified initially, 35 were included in this study. From related papers, general characteristics, study objective, eHealth-related outcomes, target populations, eHealth interventions, health service category, eHealth solution, and eHealth domain were extracted, classified, and tabulated. Most publication types were ideas, editorials, or opinions (46\%). The most targeted populations were people of the community and medical staff $(80 \%)$. The most implemented or suggested eHealth solution was telehealth $(63 \%)$, followed by mhealth, health information technology, and health data analytics. Most of the COVID-19 ehealth interventions designed or suggested for improving prevention (48\%) and diagnosis (48\%). Most of the studies applied or proposed eHealth solutions for general practice or epidemiological purposes (48\%).

Conclusion: eHealth solutions have the potential to provide useful services to help in COVID-19 pandemics in terms of prevention, diagnosis, treatment, screening, surveillance, resource allocation, education, management, and control. The obtained results from this review might be used for a better understanding of current ehealth solutions provided or recommended in response to the COVID-19 pandemic.

Keywords: COVID-19, eHealth, Telemedicine, Public health, Health informatics

Conflicts of Interest: None declared

Funding: None

*This work has been published under CC BY-NC-SA 1.0 license.

Copyright $\odot$ Iran University of Medical Sciences

Cite this article as: Eslami P, Niakan Kalhori ShR, Taheriyan M. eHealth solutions to fight against COVID-19: A scoping review of applications. Med J Islam Repub Iran. 2021 (1 Apr);35:43. https://doi.org/10.47176/mjiri.35.43

Introduction

Since december 2019, a novel human coronavirus was identified and expanded to the world. This was the start
Corresponding author: Moloud Taheriyan, m-taherian@razi.tums.ac.ir

1. Department of Health Information Management, School of Allied Medical Sciences, Tehran University of Medical Sciences, Tehran, Iran $\uparrow$ What is "already known" in this topic:

According to earlier studies, ehealth has various pandemic control applications due to the contagious nature of this virus and the need for physical distancing to reduce the transmission rate. As a response to this need, several papers were published in recent months on the usage or implementation of eHealth solutions to aid in combat the Covid-19 global health crisis.

\section{$\rightarrow$ What this article adds:}

According to this study's findings, eHealth solutions can provide useful services to help in pandemics in terms of prevention, diagnosis, treatment, screening, surveillance, resource allocation, education, management, and control. Telehealth, mHealth, health information technology, and health data analytics are the most implemented or suggested subdomains of ehealth solutions to support different aspects of COVID-19 pandemic control. 
point of the most severe type of coronavirus disease (1-3). COVID-19 or corona virus disease 2019 is a viral disease, which was caused by SARS-CoV-2. It is classified as a B type of infectious disease and has a long incubation period (1).

According to a study conducted by Lauer et al, the median incubation period for COVID-19 estimated 5.1 days (95\% CI, 4.5-5.8 days) and "this implies that under conservation assumptions, 101 out of every 10000 cases will develop symptoms after 14 days of active monitoring or quarantine." This means direct communication or contacts spread the virus rapidly (3). Thus, most of the countries that identified the prevalence of COVID-19 set quarantine and warned people to avoid crowds and stay home (1). In such a situation, information and communication technologies (ICT), emerged as a solution to ease the difficulties and solve some problems. The ICT technology, which is applied in the health area, is called eHealth. The scope of eHealth is more than just technology. "eHealth" is a broad term and defines as "an emerging field in the intersection of medical informatics, public health, and business, referring to health services and information delivered or enhanced through the Internet and related technologies." (4) It consists of finding, applying, registering, managing, transmitting, interpreting, and inferencing information in making medical decisions in supporting health care and many other purposes $(5,6)$. This technology particularly has various applications in this pandemic control; it is due to the contagious nature of this virus and the need for physical distancing to reduce the transmission rate. As a response to this need, several papers have been published in the recent months on usage or implementation of eHealth solutions to aid combat this global health crisis. Some studies were not implemented and were just as ideas or recommendations for the future. Our research aims to explore the subdomains of eHealth solutions, which are utilized or recommended to help against COVID-19 pandemic in terms of prevention, diagnosis, treatment, management, and control. The results can be used to determine where future research endeavors in this area might best be directed.

\section{Methods}

This scoping review was designed and conducted according to the principles of the preferred reporting items for systematic reviews and meta-analyses (PRISMA-SCR) guidelines $(7,8)$. All phases of data collection are displayed in the PRISMA flow diagram (Fig. 1). This study aimed to investigate the subdomains of eHealth solutions, which are mostly used or recommended to conquer COVID-19.

\section{Search Strategy}

This review was conducted on the published articles up to April 14, 2020. A comprehensive literature search was performed using 4 databases of PubMed, Scopus, Embase, and Cochrane library. The search strategy was built based on 2 concept domains of eHealth solutions and COVID19. For each concept domain, the search query comprised a combination of free text keywords identified from reference papers and controlled vocabulary terms (ie, Mesh for PubMed) (Table 1).

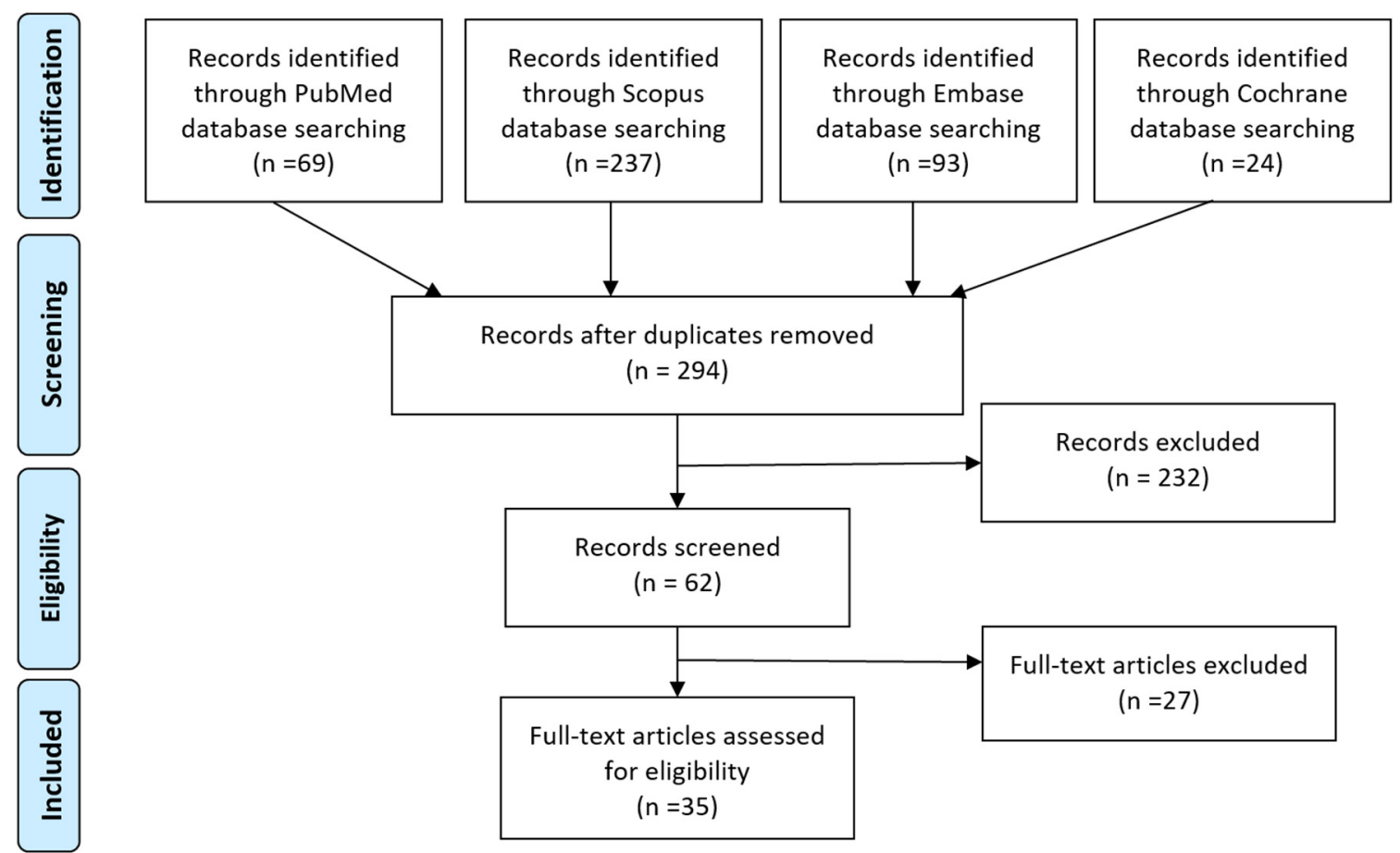

Fig. 1. Flow Diagram of the Study Selection Process Based on the Preferred Reporting Items for Systematic Reviews and Meta-Analyses (PRISMA) Framework 


\begin{tabular}{ll}
\hline Database & \multicolumn{1}{c}{ PubMed, Scopus, Embase, Cochrane } \\
\hline Limits & Language = English, Species studies= humans \\
"T & "Tele telehealth" OR "telehealth" OR "telemedicine" OR "tele-medicine" OR "telemonitor" OR "tele-monitor" OR "tel- \\
& ecare" OR "tele-care" OR "teleconsult" OR "tele-consult" OR "telecommunication" OR "tele-communication" OR "remote" \\
& OR "metry" OR "sensor" OR "sensing" OR "wearable" OR "Artificial intelligence" OR "Artificial intelligent" OR "neural \\
& network OR "Computational intelligence" OR "AI" OR "Machine inteligen*" OR "Machine learning" OR "Deep learning" \\
& OR "mining" OR Big data" OR "Pattern recognition" OR "Image processing" OR "analytics" OR "data mining" OR "mo- \\
& bile" OR "m-health" OR "m health" OR "mHealth" OR "mobile based" OR "app" OR "mobile application" OR "phone app" \\
& OR "smart phone" OR "mobile health" OR "e-health" OR "ehealth" OR "e health" OR "digital health" \\
"COVID-19" OR "COVID 19" OR "SARS-CoV-2" OR "2019-nCov" OR "Coronavirus" OR "Coronavirus" OR novel & \\
Search & corona virus" OR "novel coronavirus" OR "corona virus" OR "nCov" OR COVID 2019" \\
\hline
\end{tabular}

\section{Inclusion Criteria}

We included papers published in peer-reviewed journals that describe the implementation, usage, recommendation, or potential application of eHealth solutions in response to the COVID-19 pandemic. Because we aimed to highlight real usage as well as potential applications of eHealth related solutions in this area, all article types, such as original papers, clinical trials, ideas, editorials, opinions, news, case reports, and descriptive studies, were included.

\section{Exclusion Criteria}

Because our aim was focused on reviewing the result of studies of the ehealth-related solutions in response to COVID-19, papers that focus on other types of technologies or techniques, such as statistical or mathematical models and algorithms, were excluded. Any kind of publication other than those mentioned in inclusion criteria, such as interviews, systematic reviews, and meta-analysis, was excluded. Papers published in languages other than English as well as those for which the full-text was not available were also excluded.

\section{Selection Process}

After the removal of duplicate papers with EndNote reference management software, the articles were imported to the Rayan platform, which is a systematic review web application designed to help reviews in the systematic review blind screening process (9). Through this platform, all documents were initially screened at the title and abstract level by 2 reviewers (P.E. and M.T). At the first level, screening disagreements were resolved by consensus. At the second level for disputes cases, a third reviewer made the final decision (S.R.N.K.).

\section{Data Extraction}

Two reviewers thoroughly investigated the full- text of relevant papers, and for each document, 9 information categories were extracted using a data extraction form. The extracted data items included first author and publication year, country, study type, target population, aim of study, eHealth related outcomes, eHealth Intervention, eHealth Service category, eHealth solution, and e-Health domain. Two authors independently extracted data, and any disagreement was solved through discussions between the 3 authors.

\section{Results}

The electronic searches resulted in 423 records. After the removal of duplicates, 294 articles remained. We used the Rayyan web application for a systematic review blind screening process (43). Conducting screening based on title and abstract of articles, we defined 4 categories: Included ( $\mathrm{n}=30$ papers), Maybe ( $\mathrm{n}=13$ papers $)$, Excluded $(\mathrm{n}=232$ documents), and Conflicts ( $\mathrm{n}=19$ essays). After reaching an agreement for Maybe and Conflict categories, we studied 62 records in full-text and included 35 studies only. A variety of variables were extracted from the included studies. Extracted variables are categorized and presented in Tables 2 and 3.

\begin{tabular}{|c|c|c|c|c|c|}
\hline Author, Year & Country & Type & Target Population & Aim of the Study & eHealth Related- Outcomes \\
\hline $\begin{array}{l}\text { Grange, E. S. } \\
\text { et al., } 2020 \\
(10)\end{array}$ & USA & $\begin{array}{l}\text { Case } \\
\text { Report }\end{array}$ & $\begin{array}{c}\text { - Medical staff } \\
\text {-Health enterprises leadership } \\
\text {-Health policymakers and } \\
\text { planners } \\
\text {-People of the community }\end{array}$ & $\begin{array}{l}\text { Introduce capabilities of a na- } \\
\text { tional healthcare organization } \\
\text { Information technology services } \\
\text { to support their clinical response } \\
\text { to the COVID- } 19 \text { pandemic and } \\
\text { provide recommendations for } \\
\text { other health systems to urgently } \\
\text { consider, as they plan their } \\
\text { response to COVID-19 pandem- } \\
\text { ic. }\end{array}$ & $\begin{array}{l}\text { Information technology services and IT- } \\
\text { based solutions played an integral role in } \\
\text { responding to the COVID-19 public health } \\
\text { emergency. }\end{array}$ \\
\hline $\begin{array}{l}\text { Greenhalgh, } \\
\text { T. et al.,2020 } \\
\text { (11) }\end{array}$ & UK & $\begin{array}{l}\text { Ideas, } \\
\text { Editorials, } \\
\text { Opinions }\end{array}$ & $\begin{array}{l}\text { - Medical staff } \\
\text {-People of the community }\end{array}$ & $\begin{array}{l}\text { Discuss challenges and opportu- } \\
\text { nities and appropriate situations } \\
\text { for using } \\
\text { video consultations as a tool for } \\
\text { dealing with the COVID-19 } \\
\text { crisis. }\end{array}$ & $\begin{array}{l}\text { Given the many clinical, technical, organi- } \\
\text { zational, and policy questions raised by the } \\
\text { telehealth solutionss, the implementation } \\
\text { process of this promising technology is } \\
\text { likely to be complicated and resource inten } \\
\text { sive. It will need both national and local } \\
\text { strategic leads. It should be championed by } \\
\text { respected opinion leaders, with attention } \\
\text { paid to the overall narrative or "organizing } \\
\text { vision" within which the change is framed. }\end{array}$ \\
\hline
\end{tabular}




\begin{tabular}{|c|c|c|c|c|}
\hline $\begin{array}{l}\text { Author, } \\
\text { Year }\end{array}$ & Country & Type & Target Population & Aim of the Study \\
\hline $\begin{array}{l}\text { Hurt, B. et } \\
\text { al.,2020 (12) }\end{array}$ & USA & $\begin{array}{l}\text { Practical } \\
\text { Research }\end{array}$ & $\begin{array}{c}\text { - Medical staff } \\
\text { (physicians and radiologists) }\end{array}$ & $\begin{array}{l}\text { Describe a deep learning approach to } \\
\text { augment chest radiographs with a color } \\
\text { probability overlay to improve the diag- } \\
\text { nosis of COVID-19 pneumonia. }\end{array}$ \\
\hline $\begin{array}{l}\text { Jiang, X. et } \\
\text { al.,2020 (13) }\end{array}$ & China & $\begin{array}{l}\text { Case } \\
\text { Report }\end{array}$ & $\begin{array}{l}\text { - Medical staff } \\
\text { (mental health professionals) } \\
\text {-People of the community }\end{array}$ & $\begin{array}{l}\text { Introduce a two-pronged approach (on- } \\
\text { site and remote) implemented at the } \\
\text { national and provincial level to support } \\
\text { timely psychological crisis intervention } \\
\text { in response to mental disorders resulted } \\
\text { from the COVID-19 pandemic. }\end{array}$ \\
\hline
\end{tabular}

$\begin{array}{lcccc}\begin{array}{l}\text { Mashamba- } \\ \text { Thompson, }\end{array} & \begin{array}{c}\text { South Africa } \\ \text { and }\end{array} & \begin{array}{c}\text { Practical } \\ \text { Research }\end{array} & \text { - Medical staff } & \begin{array}{l}\text { Develop and recommend a low-cost } \\ \text { blockchain and artificial intelligence }\end{array} \\ \begin{array}{l}\text { T. P.et } \\ \text { al.,2020 (14) }\end{array} & \text { USA } & & \text {-Health enterprises leadership } & \begin{array}{l}\text { coupled mobile-linked self-testing and } \\ \text { tracking system for accurate diagnosis }\end{array} \\ & & \text {-Health policymakers and } & \text { and electronic surveillance of COVID-19 } \\ \text { in underserved populations. }\end{array}$

Mayor,

S.,2020 (15)

UK

Ideas,
Editorials,
Opinions

-People of the community

-Healthcare researchers (medical and epidemiological researchers)

-People of the community

\begin{tabular}{|c|c|c|c|}
\hline \multirow[t]{3}{*}{$\begin{array}{l}\text { McCullough, } \\
\text { P. A. et } \\
\text { al.,2020 (16) }\end{array}$} & USA and Italy & $\begin{array}{l}\text { Ideas, } \\
\text { Editorials, } \\
\text { Opinions }\end{array}$ & $\begin{array}{c}\text { - Medical staff } \\
\text {-Health enterprises leadership }\end{array}$ \\
\hline & & & $\begin{array}{l}\text {-Health policymakers and } \\
\text { planners }\end{array}$ \\
\hline & & & -People of the community \\
\hline
\end{tabular}

$\begin{array}{lccc}\text { Moazzami, } & \text { Iran } & \text { Ideas, } & \text { - Medical staff } \\ \text { B. et al.,2020 } & & \text { Editorials, } \\ \text { (17) } & & \text { Opinions } & \text {-People of the community }\end{array}$

Introduce a mobile application for COVID-19 symptoms, spread tracking, and discuss it's potentially better to understand some medical and epidemiological aspects of the disease.

Recommend take up real-time selfreporting and reporting of hospitalizations of COVID-19 as critical events and metrics of the pandemic through mobile applications as an urgent task to proper management of resource allocation and combat this pandemic.

Recommend forward triage of suspected COVID-19 patients through real-time virtual consultation platforms such as smartphones or webcam-enabled computers.
The proposed deep learning approach may have utility in early diagnosis and longitudinal followup of suspected pneumonia, including patients with COVID-19 pneumonia. In viral

epidemics such as COVID-19, which place a significant strain on the healthcare system, deep learning approaches may provide a mechanism of workload relief and earlier advanced interpretation.

Because of substantial shortcomings with remote consultation, remote psychological consultations services, cannot replace face-to-face onsite services. Therefore, in to improve efficiency and optimal use of limited medical resources in an epidemic situation such as COVID19 , implementation of the twopronged approach (onsite and remote) for psychological crisis interventions at the same time can minimize risks of cross-infections

The proposed low-cost structure can be adapted for use mainly in settings with poor access to laboratory infrastructure or resource-limited settings, help to curb the spread of COVID-19 and the related mortalities, and alleviate the burden on the health system.

The proposed application can help to identify clinical characteristics of COVID-19 patients and the people most at risk. It can monitor regional distribution and trends in the transmission of COVID-19 and help slow the outbreak through real-time tracking.

Self-reporting and reporting of hospitalizations of COVID-19 via a mobile phone application that could obtain critical information on suspected cases and report on the results of self-testing and actions taken can help proper management of technical and human resource allocation such as essential personal protective equipment and mechanical ventilators or nursing, physician, and professional staff during the pandemic.

Direct-to-consumer telemedicine could lead to a substantial decline in unnecessary patients visits and the risk of clinicians' exposure to infections, promoting self-isolation, and reducing emergency department overuse. This approach provides early screening and remote monitoring of COVID-19 patients during incubation and post-discharge period, which is a crucial step in containing the outbreak.
All studies were published in 2020. Included publications were from the USA $(\mathrm{n}=1)$, China $(\mathrm{n}=9)$, UK $(\mathrm{n}=$ 4), Italy $(\mathrm{n}=1)$, Iran $(\mathrm{n}=1)$, Sultanate of Oman $(\mathrm{n}=1)$, and Taiwan $(\mathrm{n}=1)$. In 7 studies, the authors from more than 1 country collaborated.

Based on the extracted information, we categorized the study type variable into 5 groups. Ideas, Editorials, or Opinions reflect the author's views, opinions, or recommendations on the application of eHealth-related interventions in response to COVID-19 pandemic (46\%). Case reports are reporting adaptation of eHealth interventions as tools to aid combat COVID-19 pandemic (26\%). Prac- 


\begin{tabular}{lccc}
\hline Author, Year & Country & Type & Target Population \\
\hline Nicol, G. E. & USA and Cana- & Ideas, & -Healthcare researchers (re- \\
et al.,2020 & da & Editorials, & searchers and staff engaged in \\
(18) & & Opinions & clinical research)
\end{tabular}

-People of the community (older adults engaged in clinical research)

\section{Ohannessian, France and Italy Framework R. et al.,2020 \\ Proposal} (19)

Pan, $\mathrm{X}$.

B.,2020 (20)

China

Case

Report

-Health policymakers and

planners (government)

-People of the community
Pirouz, B. et

al.,2020 (21)
Italy Practical

Research
-Healthcare researchers (medical and epidemiological researchers)
Portnoy, J. et
al.,2020 (22)

Rao, A. S. R.

S. et al.,2020

(23)

Reeves, J. J.
et al.,2020

et al.,2
(24)

Smith, A. C

et al., 2020

(25)

Szperka, C.
L. et

al.,2020 (26)
USA

Ideas,

Editorials

Opinions

USA

Practical

Research

Case

Report

\section{-Health enterprise leadership \\ -Health policymakers and planners}

-People of the community

- Medical staff

-People of the community

Medical staff

Ideas,

Editorials,

Opinions

(primary care clinicians, neurologists, and headache specialists)

-People of the community (patients with migraine)
Investigates the feasibility of artificial intelligence in the classification of confirmed cases of COVID-19 and analysis impact of environmental factors (i.e., temperature) on virus spread and survival through regression analysis.

Discuss telemedicine potentials to help the healthcare system handle sick patients, particularly those with chronic diseases like allergies in the current COVID-19 situations.

To evaluate machine learning algorithms and mobile health technologies in the preliminary screening and early identification of possible COVID-19 infected individuals as an attempt to control the rapidly spreading virus.

Describe the rapid development and implementation of the EHR based tools essential for optimizing COVID-19 outbreak management and discuss its associated challenges within a broad regional public, academic health center.

To outline critical requirements to ensure that the value of telehealth is fully realized, not only in emergencies (such as COVID-19 pandemics) but also, in everyday practice.

Outline the use of telehealth strategies for the treatment of migraine which do not require in-person visits to the clinic or the emergency

department and to describe ways that health insurance companies can remove barriers to facilitate the use of telehealth for quality care of migraine in the setting of COVID-19 infection.
eHealth Related- Outcomes

Digital tools and telehealth platforms could be used to initiate or continue research studies and even expand to meet participants' personal needs during the COVID-19 al needs during the COVID-19
crisis. The use of these technologies can keep research participants and staff safe and not contribute to the spread of the virus.

Define the conceptual framework of telemedicine for the COVID-19 pandemic and case report of its integration within health systems at the national level.

Personal-oriented digital technologies Can help individuals assess and alert to the risk of transmission and facilitates the government to conduct crisis management during the outbreak period. These informative technologies may help cut down the transmission of COVID-19 and maintain regular social order in the current emergency.

Artificial intelligence-based techniques and regression analysis may have a suitable performance capacity in COVID-19 related investigations.

Telemedicine has the potential to help patients and health providers by permitting them to give and get supportive care while minimizing their exposure to potentially infected people.

Artificial intelligence and mHealth technology can assist in healthrelated data collection and faster identification of possible cases of COVID-19in order to bring timely interventions.

The electronic health record and associated technologies are essential tools in supporting the clinical needs of a health system managing the COVID-19 pandemic and should be leveraged to their full potential.

For telehealth to be useful as part of a global or national emergency response as well as an everyday practice, it first needs to become a routinely used part of every health system.

Successful management of migraine with avoidance of in-person clinic and emergency department visits through telehealth strategies further benefits the current urgent societal goal of maintaining social distance to contain the COVID-19 pandemic. tical researches are focused on the design and implementation of eHealth technologies $(20 \%)$. Framework proposals established a framework for navigating and managing a medical or technical domain in the COVID-19 setting $(5 \%)$. Descriptive cross-sectionals are studies in which the disease or condition and potentially related factors are measured at a specific point in time for a defined population $(3 \%)$.

By investigating included studies, we identified 6 target groups for eHealth interventions: people of the community $(\mathrm{n}=28)$, medical staff $(\mathrm{n}=28)$, Health policymakers and planners $(n=8)$, Health enterprises leadership $(n=4)$, health care researchers $(n=4)$, and academic medical organizations $(\mathrm{n}=1)$. 


\begin{tabular}{lcccc}
\hline \multicolumn{5}{c}{ Target Population } \\
\hline Author, Year & Country & Type & Tactical & - Medical staff \\
Valsalan, P. & Sultanate of & Pract \\
et al., 2020 & Oman & Research & -People of the community \\
(27) & & &
\end{tabular}

Aim of the Study

Propose a remote patient health monitoring framework using IoT servers and wearable sensors as a solution for remote disease diagnosis during the COVID-19 pandemic.

Wang, C. J.
et al., 2020

(28)

$\begin{array}{cc}\text { Taiwan } & \text { Case } \\ \text { Report }\end{array}$

Case
Report

\begin{tabular}{|c|c|c|c|}
\hline & & & -People of the community \\
\hline $\begin{array}{l}\text { nd, T. R. } \\
\text { al., } 2020\end{array}$ & $\begin{array}{l}\text { Netherland } \\
\text { and Sweden }\end{array}$ & $\begin{array}{l}\text { Ideas, } \\
\text { Editorials, } \\
\text { Opinions }\end{array}$ & $\begin{array}{c}\text { - Medical staff } \\
\text {-People of the community }\end{array}$ \\
\hline
\end{tabular}

Wright, J. H.

et al., 2020

(30)

USA

Ideas,
Editorials,
Opinions

- Medical staff

-People of the community

Yang, Y. et
al. ,2020 (31)

China

Ideas,

Editorials,

Opinions

- Medical staff

-People of the community

(older adults)

$\begin{array}{lll}\text { Yasaka, T. } & \text { United States } & \text { Practical } \\ \text { M. at al. } & & \text { Research }\end{array}$

$2020(32)$
-People of the community

Development and evaluation of an effective contact tracing smartphone app for tracing possible routes of

COVID-19 transmission that respects user privacy by not collecting location information or other personal data.

It highlights the role of telehealth in providing mental health services in the context of patient isolation during the COVID-19 pandemic.

-People of the community

- Medical staff

-People of the community
To share a national experience of using online mental health services as a tool for emergency psychological crisis intervention for the COVID-19 epidemic.
eHealth Related- Outcomes

Remote health monitoring technol-

ogy such as the internet of things(IoT) and wearable sensors would be a practical solution to preventing the spread of COVID-19 infection as well as to get a proper diagnosis of the state of patient health, even if the doctor is at far distance.

Given the continual spread of COVID-19 around the world, understanding the action items and health relates to technological tools that were implemented quickly in Taiwan and assessing the effectiveness of these actions in preventing a largescale epidemic may be instructive for other countries.

Urge practitioners to promptly start adopting e-mental healthcare applications, both as methods to continue their care to current patients in need and as interventions to cope with the imminent upsurge in mental health symptoms due to the COVID-19 pandemic.

In a time of considerable uncertainty and danger like COVID-19, new and old technologies need to be mustered without delay and put into action to manage the crisis. Barriers such as confidentiality requirements, lack of technology expertise, and reimbursement issues need to be identified and solved with compassionate zeal.

There seems to be insufficient and inadequate attention paid to the older population in the recently established crisis psychological services for COVID-19. Stakeholders and health policymakers should collaborate to resolve this barrier to provide high-quality, timely crisis psychological services to community-dwelling older adults.

The proposed smartphone-based contact tracing method presents a novel solution that preserves privacy while demonstrating the potential to suppress an epidemic or pandemic outbreak. This application could potentially be applied to the current COVID-19 pandemic as well as others in the future to achieve a middle ground between drastic isolation measures and unmitigated disease spread.

Tele mental health services are ideally suited to the COVID-19 pandemic situation giving people in remote locations access to essential services without increasing the risk of infection.

Online mental health services being used for the COVID-19 epidemic eventually could improve the quality and effectiveness of emergency interventions.
Figure 2 shows the classification of included publications based on eHealth solution subdomains suggested or used for the COVID-19 pandemic. We broke down eHealth domain into 4 subdomains. The most implemented or suggested subdomain was telehealth, followed by mHealth, health information technology, and health data analytics. Thirty one out of 35 studies used, proposed, or implemented telehealth and mhealth solutions alone or in combination with other eHealth solutions. Eleven out of
35 studies applied or suggested health information technology solutions. The last implemented or proposed eHealth solution was health data analytics. Only 9 out of 35 studies implemented or suggested this eHealth solution.

By investigating the publications, we identified 11 categories as the aim of eHealth interventions, including prevention, screening, triage, diagnosis, treatment, prescription, monitoring, reporting, health resources allocation, 


$\begin{array}{cc}\text { Country } & \text { Typ } \\ \text { UK } & \text { Cas } \\ & \text { Report }\end{array}$

Type Target Population

Academic medication

Disc

Aim of the Study

Discuss the different modes of teleteaching and its challenges for medical stual., 2020 (35) Report tions (medical Schools) dents that may be offered during the

-People of the community COVID-19 pandemic. (medical students)

\begin{tabular}{|c|c|c|c|c|}
\hline $\begin{array}{l}\text { Dashraath, P. } \\
\text { et al., } 2020 \\
\text { (36) }\end{array}$ & United States & $\begin{array}{c}\text { Framework } \\
\text { Proposal }\end{array}$ & $\begin{array}{l}\text { - Medical staff } \\
\text { (COVID-19 frontline obstetric } \\
\text { care providers) } \\
\text {-people of the community } \\
\text { (Pregnant women with } \\
\text { COVID-19) }\end{array}$ & $\begin{array}{l}\text { To share a framework for Navigating the } \\
\text { pathophysiology, diagnosis and obstetric } \\
\text { management of pregnant women with } \\
\text { COVID-19 infection that built around the } \\
\text { principles include telemedicine which } \\
\text { can be adopted by tertiary maternity units } \\
\text { managing pregnant women in the flux of } \\
\text { a pandemic while maintaining the safety } \\
\text { of the patient and healthcare provider at } \\
\text { its core. }\end{array}$ \\
\hline $\begin{array}{l}\mathrm{Li}, \mathrm{Z} \text { et al., } \\
2020 \text { (37) }\end{array}$ & China & $\begin{array}{l}\text { descriptive } \\
\text { Cross- } \\
\text { Sectional }\end{array}$ & - Medical staff & $\begin{array}{l}\text { Evaluate psychological stress, especially } \\
\text { vicarious traumatization caused by the } \\
\text { COVID- } 19 \text { pandemic, in medical staff } \\
\text { via a mobile app-based } \\
\text { questionnaire }\end{array}$ \\
\hline
\end{tabular}

$\begin{array}{ll}\text { Liu, S. et al. China } & \begin{array}{c}\text { Case } \\ \text { Report }\end{array}\end{array}$

- Medical staff ,2020(38) Report (COVID-19 frontline physicians and pharmacists)

-People of the community

Waters,

Adele, 2020

UK

(39)

Ideas,
Editorials, Opinions

- Medical staff (animal health professionals)

\section{- Medical staff}

Editorials, Opinions

C., et
al.,2020 (40)

-People of the community (diabetic foot patients)

\begin{tabular}{|c|c|c|c|}
\hline $\begin{array}{l}\text { Jakhar, D, et } \\
\text { al,2020 (41) }\end{array}$ & USA & $\begin{array}{l}\text { Ideas, } \\
\text { Editorials, } \\
\text { Opinions }\end{array}$ & $\begin{array}{c}\text { - Medical staff } \\
\text { (dermatologists) }\end{array}$ \\
\hline
\end{tabular}

- Medical staff (COVID-19 front line hospital workers)
Investigate the unique needs of pharmacy services in the COVID-19 pandemic include establishing remote pharmacy services to prevent

human-to-human infections and shares these national experiences with the international pharmacy community in response to these needs.

Discuss using Veterinary telehealth and mobile health services during COVID19.

Recommend strategies to provide care for diabetic foot ulcers during COVID19 infection, including implementing a triage system to identify the urgency level of podiatric care and the use of telemedicine and Remote Patient Monitoring.

Recommend strategies for performing dermoscopy during the COVID-19 pandemic include the use of paperless approaches such as digital reporting to communicate dermoscopy reports with patients.

Implement a hospital-based infection control system to monitor and assist medical staff working in negative pressure isolation wards with COVID-19 patients in real-time via computer monitors.
eHealth Related- Outcomes

Teleteaching via online platforms

maybe a proper solution to the cancellations that are currently taking place during the COVID-19 pandemic. It can preserve student engagement and interactivity while observing appropriate COVID-19 social

distancing measures. But it cannot substitute actual student-patient meetings, which are necessary for learning and building a diagnostic clinical thought process.

The proposed integrated framework can provide an appropriate level of care for patients and hospital staff during the COVID-19 pandemic.

Early intervention of vicarious traumatization and mental stress for the general public and medical staff, as well as the transparent announcement of the epidemic information can facilitate the psychological treatment and control of COVID-19.

Focused actions such as establishing remote pharmacy services to prevent human to human transmission should be considered during the COVID-19 pandemic.

Remote health services for veterinary care reducing unnecessary travel when social distancing measures are in place and may reduce some of the pressure experienced by vet physicians and vet owners that are being impacted by COVID-19 restrictions.

Podiatrists must mobilize to provide coordinated care of the diabetic atrisk foot via shift away from hospital-based care to home telemedicine to reduce the burden on the healthcare system by keeping patients safe, functional, and at home during the COVID-19 pandemic. It becomes crucial to modify the approach of performing dermoscopy and understand various ways to prevent dermatoscopy from becoming a possible source of nosocomial spread during the COVID-19 pandemic.

The proposed observing system, as a proactive infection control tool, provides immediate prevention against

nosocomial infection in negative pressure isolation wards, which offers creative assistance to combat the

COVID-19 outbreak. education, and outbreak surveillance. Figure 3 demonstrates the frequency ratio of these health service categories. Most of the studies were applied or suggested eHealth interventions were for prevention and diagnosis.

We also break down the included publications regarding the health domain to be covered by digital interventions they applied or suggested, including general practice, medical specialty, epidemiology, medical research, and medical education. As shown in Figure 4, most of the studies applied or suggested eHealth solutions for general practice or epidemiological purposes, followed by medical specialty. In 2 studies, interventions were designed or rec- 


\begin{tabular}{|c|c|c|c|c|c|}
\hline Author, Year & Country & Type & Target Population & Aim of the Study & eHealth Related- Outcomes \\
\hline $\begin{array}{l}\text { Li, S et al., } \\
2020 \text { (3) }\end{array}$ & China & $\begin{array}{l}\text { Practical } \\
\text { Research }\end{array}$ & $\begin{array}{c}\text { - Medical staff } \\
\text { (mental health professionals) } \\
\text {-Health policymakers and } \\
\text { planners } \\
\text {-Healthcare researchers (men- } \\
\text { tal health researchers) }\end{array}$ & $\begin{array}{l}\text { Explore the impacts of public health } \\
\text { emergency COVID-19 on people's } \\
\text { mental health through a national online } \\
\text { social network data analysis, using the } \\
\text { approach of online } \\
\text { ecological recognition (OER) based on } \\
\text { several machine-learning predictive } \\
\text { models to assist policymakers in devel- } \\
\text { oping actionable policies, and help } \\
\text { clinical practitioners } \\
\text { provide timely services to affected } \\
\text { populations. }\end{array}$ & $\begin{array}{l}\text { Analyzing social media data via } \\
\text { machine learning-based psychologi- } \\
\text { cal prediction models may provide } \\
\text { timely understanding of the impact } \\
\text { of public health emergencies such } \\
\text { as the COVID-19 pandemic on the } \\
\text { public's mental health during the } \\
\text { epidemic period in a noninvasive } \\
\text { way. }\end{array}$ \\
\hline $\begin{array}{l}\text { Boulos MN, } \\
\text { Geraghty } \\
\text { EM., } 2020 \\
(42)\end{array}$ & China & $\begin{array}{l}\text { Ideas, } \\
\text { Editorials, } \\
\text { Opinions }\end{array}$ & $\begin{array}{l}\text {-Health policymakers and } \\
\text { planners } \\
\text {-People of the community }\end{array}$ & $\begin{array}{l}\text { Offers pointers to and describes a range } \\
\text { of practical online/mobile GIS and } \\
\text { mapping dashboards and applications for } \\
\text { tracking the COVID- } 19 \text { epidemic and } \\
\text { associated events as they unfold around } \\
\text { the world and discuss additional ways } \\
\text { GIS can support the fight against infec- } \\
\text { tious disease outbreaks and epidemics. }\end{array}$ & $\begin{array}{l}\text { Modern GIS technologies improved } \\
\text { data sharing and real-time infor- } \\
\text { mation to support critical decision- } \\
\text { making. Dashboards exemplify } \\
\text { those ideals and have been extreme- } \\
\text { ly popular in sharing and under- } \\
\text { standing the spread of COVID-19. } \\
\text { Communication through map-based } \\
\text { dashboards offers accessible infor- } \\
\text { mation to people around the world } \\
\text { eager to protect themselves and } \\
\text { their communities. This tool type } \\
\text { improves data transparency and } \\
\text { helps authorities disseminate infor- } \\
\text { mation. }\end{array}$ \\
\hline
\end{tabular}

\begin{tabular}{|c|c|c|c|c|}
\hline Autor, Year & eHealth Intervention & eHealth Service Category & eHealth Solution & e-Health domain \\
\hline $\begin{array}{l}\text { Grange, E. S. et al., } \\
2020(10)\end{array}$ & $\begin{array}{l}\text { IT integration hospital incident command } \\
\text { system, Real-time dashboards, EHR, } \\
\text { Clinical decision support, Newsletter } \\
\text { websites, E-mail platforms, Short massage } \\
\text { services, Ambulatory and clinical visit } \\
\text { telehealth services }\end{array}$ & $\begin{array}{c}\text {-Screening } \\
\text {-Diagnosis } \\
\text {-Treatment } \\
\text { - Resource allocation }\end{array}$ & $\begin{array}{c}\text {-HITS } \\
\text {-Telehealth }\end{array}$ & $\begin{array}{l}\text {-General practice } \\
\text {-Epidemiology }\end{array}$ \\
\hline $\begin{array}{l}\text { Greenhalgh, T. et al., } \\
2020 \text { (11) }\end{array}$ & $\begin{array}{l}\text { Teleconsultation services : Video consul- } \\
\text { tation }\end{array}$ & $\begin{array}{l}\text {-Diagnose } \\
\text {-Treatment }\end{array}$ & -Telehealth & -General Practice \\
\hline $\begin{array}{l}\text { Hurt, B. et al., } 2020 \\
\text { (12) }\end{array}$ & $\begin{array}{l}\text { Deep learning-based algorithm for diag- } \\
\text { nosis COVID-19 pneumonia }\end{array}$ & $\begin{array}{l}\text {-Diagnosis } \\
\text {-Monitoring }\end{array}$ & -HDA & -Radiology \\
\hline $\begin{array}{l}\text { Jiang, X. et al., } 2020 \\
\text { (13) }\end{array}$ & $\begin{array}{l}\text { Remote consultation and prescription : } \\
\text { telephone, internet, third-party online } \\
\text { platforms }\end{array}$ & $\begin{array}{c}\text {-Diagnosis } \\
\text {-Treatment } \\
\text {-Prescription }\end{array}$ & -Telehealth & -Psychology/ Psychiatry \\
\hline $\begin{array}{l}\text { Mashamba-Thompson, } \\
\text { T. P. et al., } 2020 \text { (14) }\end{array}$ & $\begin{array}{l}\text { Self-testing and tracking system based on } \\
\text { m-health, blockchain, GIS and AI tech- } \\
\text { nology }\end{array}$ & $\begin{array}{c}\text {-Diagnosis } \\
\text {-Treatment } \\
\text {-Monitoring } \\
\text {-Outbreak surveillance }\end{array}$ & $\begin{array}{l}\text {-MHealth } \\
\text {-HDA }\end{array}$ & $\begin{array}{l}\text {-General Practice } \\
\text {-Epidemiology }\end{array}$ \\
\hline Mayor, S.,2020 (15) & $\begin{array}{l}\text { Mobile-base symptom tracker application } \\
\text { for COVID-19 }\end{array}$ & $\begin{array}{c}\text {-Prevention } \\
\text {-Outbreak surveillance }\end{array}$ & -MHealth & $\begin{array}{l}\text {-General Practice } \\
\text {-Health Research (medical and } \\
\text { epidemiological research) }\end{array}$ \\
\hline $\begin{array}{l}\text { McCullough, P. A. et } \\
\text { al., } 2020(16)\end{array}$ & $\begin{array}{l}\text { Self-reporting, reporting, and self-testing : } \\
\text { Mobile application, Social media website }\end{array}$ & $\begin{array}{l}\text {-Screening } \\
\text {-Outbreak surveillance } \\
\text {-Resource allocation }\end{array}$ & $\begin{array}{l}\text {-MHealth } \\
\text {-HITS }\end{array}$ & $\begin{array}{l}\text {-General Practice } \\
\text {-Epidemiology }\end{array}$ \\
\hline $\begin{array}{l}\text { Moazzami, B. et al., } \\
2020 \text { (17) }\end{array}$ & $\begin{array}{l}\text { Real-time virtual consultation platforms: } \\
\text { Smartphones, Webcam-enabled comput- } \\
\text { ers }\end{array}$ & -Screening & -Telehealth & -General Practice \\
\hline $\begin{array}{l}\text { Nicol, G. E. et al., } 2020 \\
\text { (18) }\end{array}$ & $\begin{array}{l}\text { Digital tools to conduct research and care } \\
\text { remotely: } \\
\text { Electronic informed consent, E-mailed } \\
\text { surveys, EHR, Telephone, e-mail, or } \\
\text { video conferencing for virtual study visits, } \\
\text { Telephone-based depression care man- } \\
\text { agement, Digital forum for the sharing of } \\
\text { approaches and ideas between researchers }\end{array}$ & $\begin{array}{l}\text {-Prevention } \\
\text {-Screening } \\
\text {-Diagnosis } \\
\text {-Treatment }\end{array}$ & $\begin{array}{c}\text {-HITS } \\
\text {-Telehealth }\end{array}$ & $\begin{array}{l}\text {-Health Research (geriatric re- } \\
\text { search) }\end{array}$ \\
\hline $\begin{array}{l}\text { Ohannessian, R. et al., } \\
2020 \text { (19) }\end{array}$ & $\begin{array}{l}\text { Remote triage via online auto question- } \\
\text { naire, Teleconsultation, Teleexpertise, } \\
\text { Telemonitoring, Telecare, Teleradiology, } \\
\text { Tele ICU }\end{array}$ & $\begin{array}{l}\text {-Triage } \\
\text {-Diagnosis } \\
\text {-Treatment } \\
\text {-Monitoring }\end{array}$ & -Telehealth & -General Practice \\
\hline Pan, X. B., 2020 (20) & $\begin{array}{l}\text { Personal-oriented and mobile phone-based } \\
\text { information technologies for preventing } \\
\text { COVID- } 19 \text { transmission }\end{array}$ & $\begin{array}{c}\text {-Prevention } \\
\text {-Outbreak surveillance }\end{array}$ & $\begin{array}{l}\text {-MHealth } \\
\text {-HDA }\end{array}$ & -General Practice \\
\hline
\end{tabular}

ommended to cover the health research domain, and in 1 study eHealth interventions were utilized for medical education. 


\begin{tabular}{|c|c|c|c|c|}
\hline Autor, Year & eHealth Intervention & $\begin{array}{l}\text { eHealth Service } \\
\text { Category }\end{array}$ & $\begin{array}{l}\text { eHealth Solu- } \\
\text { tion }\end{array}$ & e-Health domain \\
\hline $\begin{array}{l}\text { Pirouz, B. et } \\
\text { al., } 2020(21)\end{array}$ & $\begin{array}{l}\text { Regression analysis and a binary classification model base on the } \\
\text { group method of data handling (GMDH) type of neural network }\end{array}$ & -Diagnosis & -HDA & $\begin{array}{l}\text {-General Practice } \\
\text {-Epidemiology }\end{array}$ \\
\hline $\begin{array}{l}\text { Portnoy, J. et } \\
\text { al., } 2020(22)\end{array}$ & $\begin{array}{l}\text { Telehealth for office-based encounters to isolate providers, Home- } \\
\text { based video encounters for triage, Telemedicine services for the } \\
\text { management of the chronic condition }\end{array}$ & $\begin{array}{l}\text {-Screening } \\
\text {-Triage } \\
\text {-Diagnosis } \\
\text {-Treatment } \\
\text {-Monitoring }\end{array}$ & -Telehealth & $\begin{array}{l}\text {-General Practice (chronic dis- } \\
\text { ease management, particularly } \\
\text { allergists) }\end{array}$ \\
\hline $\begin{array}{l}\text { Rao, A. S. R. } \\
\text { S. et al., } 2020 \\
\text { (23) }\end{array}$ & $\begin{array}{l}\text { Mobile-phone online survey for data collection, Machine learning } \\
\text { algorithms for data analysis }\end{array}$ & -Screening & $\begin{array}{l}\text {-HDA } \\
\text {-MHealth }\end{array}$ & -General Practice \\
\hline $\begin{array}{l}\text { Reeves, J. J. et } \\
\text { al., } 2020 \text { (24) }\end{array}$ & $\begin{array}{l}\text { EHR based informatics tools: Operational dashboard, Clinical deci- } \\
\text { sion support, secured massaging platform, Reporting/analytics tools, } \\
\text { Video visits for outpatient clinic encounters }\end{array}$ & $\begin{array}{c}\text {-Prevention } \\
\text {-Screening } \\
\text {-Diagnosis } \\
\text {-Treatment } \\
\text {-Outbreak surveil- } \\
\text { lance }\end{array}$ & $\begin{array}{l}\text {-HITS } \\
\text {-MHealth } \\
\text {-Telehealth }\end{array}$ & $\begin{array}{l}\text {-General Practice } \\
\text {-Epidemiology }\end{array}$ \\
\hline $\begin{array}{l}\text { Smith, A. C. et } \\
\text { al., } 2020(25)\end{array}$ & Telehealth services for emergencies like COVID-19 & $\begin{array}{l}\text {-Prevention } \\
\text {-Triage } \\
\text {-Diagnosis } \\
\text {-Treatment }\end{array}$ & -Telehealth & -General Practice \\
\hline $\begin{array}{l}\text { Szperka, C. L. } \\
\text { et al., } 2020 \\
\text { (26) }\end{array}$ & $\begin{array}{l}\text { Remote treatment of migraine: Telemedicine services and telephone } \\
\text { visits }\end{array}$ & $\begin{array}{l}\text {-Prevention } \\
\text {-Treatment }\end{array}$ & -Telehealth & -Neurology \\
\hline $\begin{array}{l}\text { Valsalan, P. et } \\
\text { al., } 2020(27)\end{array}$ & $\begin{array}{l}\text { Remote portable health monitoring framework includes room and } \\
\text { patient monitoring sensors, IOT servers, internet communication, } \\
\text { and smartphone }\end{array}$ & $\begin{array}{l}\text {-Screening } \\
\text {-Prevention } \\
\text {-Diagnose } \\
\text {-Treatment } \\
\text {-Monitoring }\end{array}$ & $\begin{array}{l}\text {-MHealth } \\
\text {-Telehealth } \\
\text {-HITS }\end{array}$ & -General Practice \\
\hline $\begin{array}{l}\text { Wang, C. J. et } \\
\text { al., } 2020(28)\end{array}$ & $\begin{array}{l}\text { Big data analytics, Real-time alerts, QR code scanning, Case report- } \\
\text { ing Hotlines, Short massage services, Mobile-based application, and } \\
\text { electronic entry cards, Internet base public service announcements } \\
\text { broadcast }\end{array}$ & $\begin{array}{l}\text {-Prevention } \\
\text {-Screening } \\
\text {-Diagnosis } \\
\text {-Monitoring } \\
\text {-Resource alloca- } \\
\text { tion }\end{array}$ & $\begin{array}{l}\text {-HITS } \\
\text {-MHealth } \\
\text {-HDA }\end{array}$ & -General Practice \\
\hline $\begin{array}{l}\text { Wind, T. R. et } \\
\text { al., } 2020(29)\end{array}$ & $\begin{array}{l}\text { e-mental health services: Videoconferencing psychotherapy, Internet } \\
\text { interventions, Self-help apps, Online therapeutic modules }\end{array}$ & $\begin{array}{l}\text {-Prevention } \\
\text {-Treatment }\end{array}$ & $\begin{array}{l}\text {-Telehealth } \\
\text {-MHealth }\end{array}$ & -Psychology/ Psychiatry \\
\hline $\begin{array}{l}\text { Wright, J. H. et } \\
\text { al., } 2020(30)\end{array}$ & $\begin{array}{l}\text { Tele mental and behavioral health services: E-mail, Telephone, } \\
\text { Video conferencing, Computer-assisted programs, Mobile-based } \\
\text { applications }\end{array}$ & $\begin{array}{l}\text {-Prevention, } \\
\text {-Treatment, } \\
\text {-Prescription }\end{array}$ & $\begin{array}{l}\text {-Telehealth } \\
\text {-MHealth } \\
\text {-HITS }\end{array}$ & -Psychology/ Psychiatry \\
\hline $\begin{array}{l}\text { Yang, Y. et } \\
\text { al., } 2020(31)\end{array}$ & Online mental health services: Internet and smartphones & Not Clarified & $\begin{array}{l}\text {-Telehealth } \\
\text {-MHealth }\end{array}$ & $\begin{array}{l}\text {-Psychology/ Psychiatry } \\
\text { (geriatric psychology and geriat- } \\
\text { ric psychiatry) }\end{array}$ \\
\hline $\begin{array}{l}\text { Yasaka, T. M. } \\
\text { et al. } 2020 \text { (32) }\end{array}$ & Contact tracing smartphone application & -Prevention & -MHealth & $\begin{array}{l}\text {-General Practice } \\
\text {-Epidemiology }\end{array}$ \\
\hline $\begin{array}{l}\text { Zhou, X. et al., } \\
2020(33)\end{array}$ & $\begin{array}{l}\text { Tele-mental health services: Video conferencing, Online forums, } \\
\text { Online self-help, Platforms, Smartphone apps, Text messaging and e- } \\
\text { mails }\end{array}$ & $\begin{array}{l}\text {-Diagnosis } \\
\text {-Treatment } \\
\text {-Monitoring } \\
\text {-Education }\end{array}$ & $\begin{array}{l}\text {-Telehealth } \\
\text {-M-health } \\
\text {-HITS }\end{array}$ & -Psychology/ Psychiatry \\
\hline $\begin{array}{l}\text { Liu, S. et al., } \\
2020(34)\end{array}$ & $\begin{array}{l}\text { Psychological assistance hotlines, } \\
\text { Online psychological counseling services, Communication programs, } \\
\text { and e-books, Online psychological self-help intervention systems, AI } \\
\text { base emergency psychological crisis intervention system }\end{array}$ & $\begin{array}{l}\text {-Prevention } \\
\text {-Diagnosis, } \\
\text {-Treatment } \\
\text {-Education }\end{array}$ & $\begin{array}{l}\text {-Telehealth } \\
\text {-HITS } \\
\text {-HDA }\end{array}$ & -Psychology/ Psychiatry \\
\hline $\begin{array}{l}\text { Mian, A. et al., } \\
2020(35)\end{array}$ & Teleteaching via online platforms: Video-conferencing & $\begin{array}{l}\text {-Prevention } \\
\text {-Education }\end{array}$ & -Telehealth & -Medical Education \\
\hline $\begin{array}{l}\text { Dashraath, P. } \\
\text { et al., } 2020 \\
\text { (36) }\end{array}$ & $\begin{array}{l}\text { Ambulatory antenatal care of pregnant woman via telemedicine: } \\
\text { Video conferencing platforms }\end{array}$ & -Prevention & -Telehealth & -Obstetrics and Gynecology Care \\
\hline $\begin{array}{l}\mathrm{Li}, \mathrm{Z} \text { et al., } \\
2020(37)\end{array}$ & Mobile app-based questionnaire survey & $\begin{array}{l}\text {-Screening } \\
\text {-Diagnosis }\end{array}$ & -MHealth & -Psychology/ Psychiatry \\
\hline $\begin{array}{l}\text { Liu, S. et al. } \\
\text {,2020 (38) }\end{array}$ & $\begin{array}{l}\text {-Remote pharmacy services: } \\
\text { Online drug prescribing, Drug consultation and drug delivery ser- } \\
\text { vices, Drug shortage surveillance and early warning } \\
\text { the platform, Social communication mobile platforms, internet } \\
\text { articles }\end{array}$ & $\begin{array}{l}\text {-Prevention } \\
\text {-Prescription } \\
\text {-Education } \\
\text {-Resource alloca- } \\
\quad \text { tion }\end{array}$ & $\begin{array}{l}\text {-Telehealth } \\
\text {-MHealth }\end{array}$ & -Pharmaceutical Care \\
\hline $\begin{array}{l}\text { Waters, A, } \\
2020(39)\end{array}$ & $\begin{array}{l}\text { Telehealth services and mobile applications for remote veterinary } \\
\text { consultations }\end{array}$ & $\begin{array}{l}\text {-Diagnosis } \\
\text {-Treatment } \\
\text {-Prescription }\end{array}$ & $\begin{array}{l}\text {-Telehealth } \\
\text {-MHealth }\end{array}$ & -Veterinary Medicine \\
\hline
\end{tabular}

\section{Discussion}

At the beginning of the prevalence of novel coronavirus, most of the countries in the world applied seriously infec- tion-control solutions to protect people of the community as well as the medical workers from COVID-19 infectious (44). The application of these solutions drew global 


\begin{tabular}{|c|c|c|c|c|}
\hline \multicolumn{5}{|l|}{ Table 3. Ctd } \\
\hline Autor, Year & eHealth Intervention & $\begin{array}{c}\text { eHealth Service } \\
\text { Category }\end{array}$ & eHealth Solution & e-Health domain \\
\hline $\begin{array}{l}\text { Rogers, Lee C., } \\
\text { et al, } 2020(40)\end{array}$ & $\begin{array}{l}\text { Remote podiatric care services: Pandemic diabetic foot } \\
\text { triage system, In-home visits via house calls, Text video } \\
\text { chat applications, Remote patient monitoring through } \\
\text { temperature sensing devices }\end{array}$ & $\begin{array}{l}\text {-Prevention } \\
\text {-Triage } \\
\text {-Screening } \\
\text {-Prescription }\end{array}$ & $\begin{array}{l}\text {-Telehealth } \\
\text {-MHealth }\end{array}$ & -Diabetic Foot Care \\
\hline $\begin{array}{l}\text { Jakhar, D, et al, } \\
2020(41)\end{array}$ & Digital reporting & Reporting & -HITS & -Dermatology \\
\hline $\begin{array}{l}\text { Chen, X, et al., } \\
2020 \text { (1) }\end{array}$ & A hospital-based infection control system & Monitoring & -Telehealth & -General Practice \\
\hline $\begin{array}{l}\mathrm{Li}, \mathrm{S}, \text { et al, } \\
2020(3)\end{array}$ & $\begin{array}{l}\text { Text data analysis using Online Ecological Recognition } \\
\text { (OER) approach }\end{array}$ & -Prevention & -HDA & -Psychology/ Psychiatry \\
\hline $\begin{array}{l}\text { Boulos MN, } \\
\text { Geraghty EM., } \\
2020(42)\end{array}$ & $\begin{array}{l}\text { Online tracking and notification services: Geographic } \\
\text { information systems, Mapping dashboards, } \\
\text { Mobile applications for real-time outbreak surveillance }\end{array}$ & $\begin{array}{l}\text { - Outbreak sur- } \\
\text { veillance }\end{array}$ & $\begin{array}{l}\text {-MHealth } \\
\text {-HITS } \\
\text {-HDA }\end{array}$ & $\begin{array}{c}\text {-Health Geography } \\
\text {-Epidemiology } \\
\text { ( HITS, health information technology } \\
\text { services, HAD, health data analytics) }\end{array}$ \\
\hline
\end{tabular}

Publications by eHealth solutions

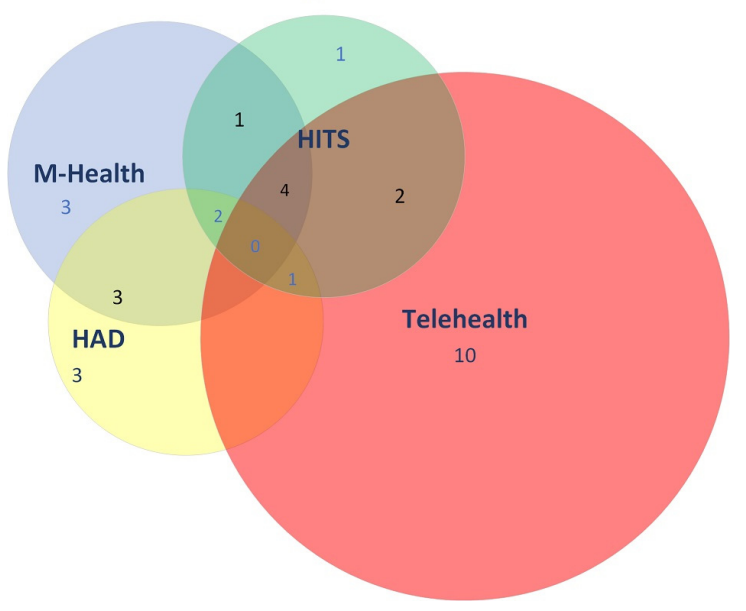

Fig. 2. eHealth Solutions of Selected Studies

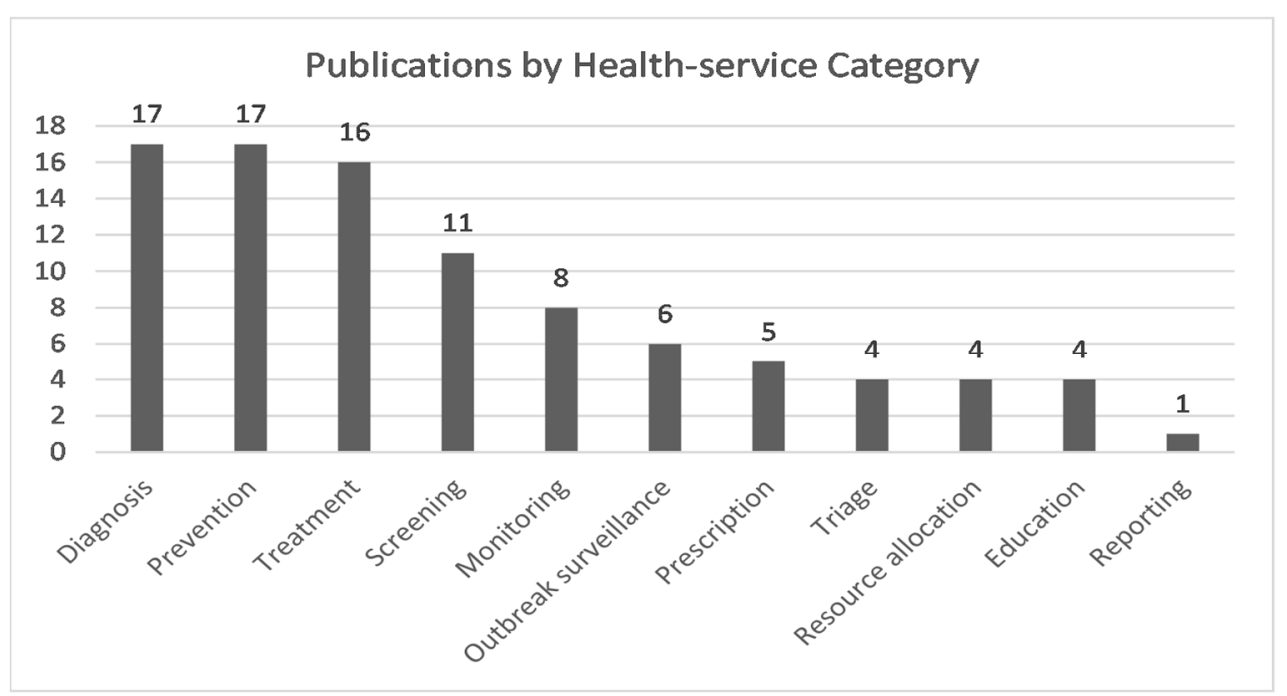

Fig. 3. Health-service Categories of Selected Studies

attention to eHealth solutions as a cost-effective and secure approach for outbreak management. As a result, several studies have been performed considering application or suggestion of technology to support different aspects of pandemic control $(1,10,13,20,24,28,34,35,38)$. Some studies are national or organizational case reports on the utilization of eHealth solutions, and some studies also have been done to create guidelines or frameworks on how to use technology in medical workflow with the lowest contacts $(1,10,13,19,20,24,28,34-36,38)$. A majority of publications discuss potential applications for using different subdomains of eHealth solutions along with their challenges and opportunities. A smaller number of studies conducted practical research with the implementation of 


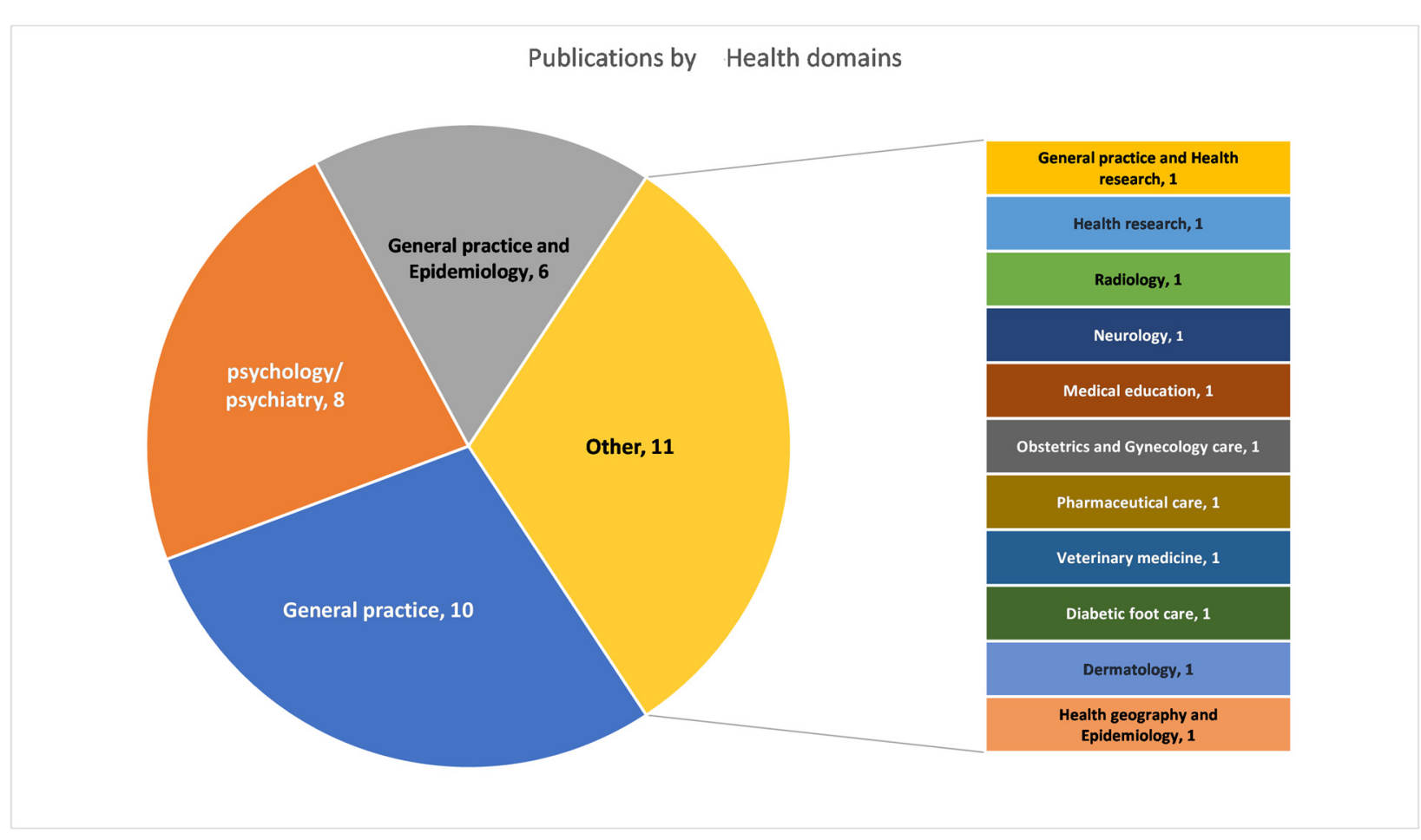

Fig. 4. Health Domains of Selected Studies

more innovative eHealth technologies, such as machine learning or artificial intelligence-based solutions (3, 12, $14,20,21,23,28,34,42,45,46)$. By investigating extracted information from selected studies, we identify significant eHealth subdomains solutions, including telehealth, mobile health, health information technology solutions, and Health data analytics, which are explained briefly in the following sections.

\section{1) Telehealth}

Telehealth is a subcategory of ehealth solutions that are used for medical information exchanged from 1 site to another through electronic communication to deliver health-related care, diagnosis, consultation, treatment, intervention, monitoring, and education at a distance (47, 48). The primary response strategy included self-isolation and mandatory quarantine to avoid direct contacts and decrease the risk of transmission (47-49). This strategy creates a need to replace another communication approach, such as telehealth. Our included studies investigated different aspects related to the integration of telehealth services in 3 pillars of modern-day medical practice, including clinical practice, medical research, and education during the COVID-19 crisis. Potential applications, the possibility of implementation as well as benefits and barriers of applying this technology in different aspects of today's medical practice are discussed in included studies. In 1 study, an updated conceptual framework for telemedicine implementation to conquer the COVID-19 pandemic presented (19).

Our included studies applied telehealth in both general practice and specialized medical services. A notable portion of studies highlights the use of telemental health ser- vices for analyzing and managing mental health issues $(13,29-31,33,34)$. Some studies suggested telehealth services for chronic disease management, such as migraine or diabetes $(26,40)$. Some studies recommend the use of telehealth services for more vulnerable populations, such as frontline health workers or older patients and practitioners $(18,31,32)$. Telehealth also can be used as a valuable tool for animal care during the COVID-19 crisis (39). Telehealth was also applied in remote drug delivery $(38,39)$. Medical institutions across China have launched remote pharmacy services for online drug prescribing, drug consultation, drug delivery, and drug shortage management (38). Telehealth can be used for conducting health research during COVID-19 (18). Nicol, G. E. et al. recommend clinical researchers working with vulnerable populations like older adults to remotely perform and continue research studies by using telehealth platforms (18). Telehealth is also suggested as a substitute method of delivering medical education in the time of the COVID-19 pandemic. A study conducted in a national medical college used tale teaching via online platforms (35). Most of the studies did not indicate a specific platform to deliver telehealth services. Among included publications, video consultation, and video-conferencing were the most applied or suggested approaches for health care professionals and clinicians to communicate and share experiences. Most of the included studies, which used telehealth services, found that as an effective way to deal with and control the COVID-19 pandemic $(11,35,39)$.

\section{2) Mobile Health}

Mobile health or mHealth is a subcategory of eHealth solutions that are used for the practice of medicine and 
public health supported by mobile devices. Increasing the use of smartphones coupled with the increasing availability of other mobile and wearable devices make it possible to utilize mobile technology in health care delivery. Inbuilt geographic information systems (GIS) in mobile devices enabled the tracking of the COVID-19 epidemic and associated events $(27,42)$. Using location-based technologies raises some issues regarding privacy. Yasaka, $\mathrm{T}$ $\mathrm{M}$, et al developed a contact tracing smartphone application for tracing possible routes of COVID-19 transmission. They present a novel solution that respects user privacy by not collecting location information or other personal data (32). mHealth solutions can also be used for proper management of self and mandatory isolation or resource allocation $(16,24,28)$. In a study related to Taiwan crisis management, a geographical tracking application used to track suspicious people during the incubation period to ensure mandatory isolation (28). The entry of COVID-19 had a negative impact on the countries' economic status. Mashamba-Thompson, T. P. et al. developed a low-cost blockchain and artificial intelligence coupled mobile-linked self-testing and tracking system for accurate diagnosis and electronic surveillance of COVID-19 in underserved populations. They suggested that their proposed structure help curb the spread of COVID-19 and the related mortalities and alleviate the burden on the health system, particularly in resource-limited settings (14). Valsalan P. et al proposed a remote patient health monitoring framework using IoT servers and wearable sensors as a solution for remote disease diagnosis during the COVID-19 pandemic (27). mHealth technology can also be used to facilitate health researches during the COVID19 pandemic (15). Zhenyu Li et al performed a study to evaluate psychological stress caused by the COVID-19 pandemic in hospital nurses (37).

\section{3) Health Information Technology Solutions (HITS)}

Health information technology solutions are eHealth tools designed to support health information management to improve integration, quality, and efficiency of health care work processes and provide real-time communications of health informatics among health care professionals $(50,51)$. In the health domain, health information systems and electronic health records are applicable tools that have a significant role in health care management. UW Medicine, a national health care organization, utilized information technology solutions to support their clinical response to the COVID-19 pandemic. Their experience demonstrated that information technology solutions and IT-based solutions could play an integral role in responding to COVID-19 public health emergencies (10). Taiwan's national experience in response to COVID-19 demonstrated that the integration of national health insurance, immigration, and custom databases helps Taiwan decision makers to manage the crisis (28).

J Reeves, J. J. et al highlighted the application of health information technology solutions to support the outbreak response in an academic health system. They built multiple COVID-19-specific tools against the outbreak. Based on their study, the electronic health record and associated technologies are essential tools in supporting the clinical needs of the health system managing the COVID-19 pandemic and should be leveraged to their full potential (24).

\section{4) Health Data Analytics (HAD)}

Data and information are valuable resources. Health data analytics as a subcategory of eHealth tools utilize techniques to infer or recognize patterns or extract rules. These tools are mainly used by health professionals to improve clinical decision making in complex situations $(45,46)$, such as the COVID-19 pandemic. Machinelearning methods, such as deep learning, are nowadays widely applied in the field of radiology for medical image processing $(52,53)$. In the case of COVID-19, Hurt, B. et al proposed a deep-learning approach to improve the diagnosis and longitudinal follow-up of COVID-19 pneumonia. They concluded that in viral epidemics such as COVID-19, deep learning approaches might provide a mechanism of workload relief and earlier advanced interpretation $(12,53)$. Artificial intelligence (AI) is another innovative technology to fight against COVID-19. This technology plays an essential role in detecting the cluster of cases and to predict where this virus will affect in the future by collecting and analyzing all previous data (54). Pirouz, B. et al developed a neural network algorithm for calcification of COVID-19 confirmed cases. Their study demonstrated the suitable performance capacity of AIbased techniques in COVID-19 related investigations (21). Some studies suggested the integration of health data analytics with other eHealth solutions such as mHealth. Rao, A. S. R. S. et al proposed an AI framework coupled with a mobile phone-based survey for COVID-19 preliminary screening and early case identification. They concluded that AI and mHealth technology could assist in healthrelated data collection and faster identification of possible cases of COVID-19 to bring timely interventions (23). Another valuable approach in this area is big data analytics. This could potentially help to understand the nature of the new coronavirus through processing and visualization of massive and unstructured data, such as medical images, patient records, social networks, and other sources, and thus facilitating prevention and treatment process during COVID-19. In a study related to Taiwan's response to COVID-19, big data analytics were utilized for analyzing national and regional databases to help identify suspicious cases for the track (28). Liu, S. et al, in their study to highlight online mental health, discussed the use of big data analytics for psychological crises intervention during COVID-19 epidemic. The program they mentioned recognizes individuals at risk of suicide during the COVID-19 pandemic by analyzing and monitoring massages people post on china national social network called Weibo and alert designated volunteers to act accordingly (34).

\section{Limitation}

Our research results had a limitation of databases we accessed, as we searched in PubMed, Scopus, Embase, and Cochrane databases, and more databases such as Web of Science could be considered for further reviews. 


\section{Conclusion}

eHealth solutions have the potential to provide useful services to help in pandemics in terms of prevention, diagnosis, treatment, screening, surveillance, resource allocation, education, management, and control. The obtained results from this scoping review might be used for a better understanding of current ehealth solutions provided or recommended in response to the COVID-19 pandemic. It is also recommended to identify the possibility of implementation in different settings as well as the benefits and barriers of applying this technology in various aspects of today's medical practice.

\section{Conflict of Interests}

The authors declare that they have no competing interests.

\section{References}

1. Chen X, Tian J, Li G, Li G. Initiation of a new infection control system for the COVID-19 outbreak. Lancet Infect Dis. 2020;20(4):397-8

2. Lauer SA, Grantz KH, Bi Q, Jones FK, Zheng Q, Meredith HR, et al. The incubation period of coronavirus disease 2019 (COVID-19) from publicly reported confirmed cases: estimation and application. Ann Intern Med. 2020

3. Li S, Wang Y, Xue J, Zhao N, Zhu T. The impact of COVID-19 epidemic declaration on psychological consequences: a study on active Weibo users. Int J Environ Res Public Health. 2020;17(6):2032.

4. Gunther E. What is e-Health? J Medical Internet Res. 2001;3(2):e20.

5. Organization WH. [Available from:
[A https://www.who.int/dg/speeches/detail/who-director-general-sopening-remarks-at-the-media-briefing-on-covid-19---25-may-2020.

6. Organization(WHO) WH. eHealth [Available from: https://www.who.int/ehealth/en/.

7. Liberati A, Altman DG, Tetzlaff J, Mulrow C, Gøtzsche PC, Ioannidis JPA, et al. The PRISMA statement for reporting systematic reviews and meta-analyses of studies that evaluate health care interventions: explanation and elaboration. J Clin Epidemiol. 2009;62(10):e1-e34.

8. Tricco AC, Lillie E, Zarin W, O'Brien KK, Colquhoun H, Levac D, et al. PRISMA extension for scoping reviews (PRISMA-ScR): checklist and explanation. Ann Intern Med. 2018;169(7):467-73.

9. Rayyan. 2020 [Available from: https://rayyan.qcri.org/

10. Grange ES, Neil EJ, Stoffel M, Singh AP, Tseng E, Resco-Summers $\mathrm{K}$, et al. Responding to COVID-19: The UW Medicine Information Technology Services Experience. Appl Clin Inform. 2020;11(02):26575 .

11. Greenhalgh T, Wherton J, Shaw S, Morrison C. Video consultations for covid-19. British Medical Journal Publishing Group; 2020.

12. Hurt B, Kligerman S, Hsiao A. Deep Learning Localization of Pneumonia: 2019 Coronavirus (COVID-19) Outbreak. J Thorac Imaging. 2020;35(3):W87-W9.

13. Jiang X, Deng L, Zhu Y, Ji H, Tao L, Liu L, et al. Psychological crisis intervention during the outbreak period of new coronavirus pneumonia from experience in Shanghai. Psychiatry Res. 2020:112903.

14. Mashamba-Thompson TP, Crayton ED. Blockchain and Artificial Intelligence Technology for Novel Coronavirus Disease-19 SelfTesting. Multidisciplinary Digital Publishing Institute; 2020.

15. Mayor S. Covid-19: Researchers launch app to track spread of symptoms in the UK. British Medical Journal Publishing Group; 2020.

16. McCullough PA, Eidt J, Rangaswami J, Lerma E, Tumlin J, Wheelan $\mathrm{K}$, et al. Urgent need for individual mobile phone and institutional reporting of at home, hospitalized, and intensive care unit cases of SARS-CoV-2 (COVID-19) infection. Rev Cardiovasc Med. 2020;21(1):1-7.

17. Moazzami B, Razavi-Khorasani N, Moghadam AD, Farokhi E, Rezaei N. COVID-19 and telemedicine: Immediate action required for maintaining healthcare providers well-being. J Clin Virol. 2020:104345

18. Nicol GE, Piccirillo JF, Mulsant BH, Lenze EJ. Action at a distance: geriatric research during a pandemic. J Am Geriatr Soc. 2020.

19. Ohannessian R, Duong TA, Odone A. Global telemedicine implementation and integration within health systems to fight the COVID-19 pandemic: a call to action. JMIR Public Health Surveill. 2020;6(2):e18810.

20. Pan X-B. Application of personal-oriented digital technology in preventing transmission of COVID-19, China. Ir J Med Sci. 2020:1

21. Pirouz B, Shaffiee Haghshenas S, Shaffiee Haghshenas S, Piro P. Investigating a serious challenge in the sustainable development process: analysis of confirmed cases of COVID-19 (new type of coronavirus) through a binary classification using artificial intelligence and regression analysis. Sustainability. 2020;12(6):2427.

22. Portnoy J, Waller M, Elliott T. Telemedicine in the Era of COVID19. J. Allergy Clin. Immunol Pract.2020.

23. Rao ASRS, Vazquez JA. Identification of COVID-19 can be quicker through artificial intelligence framework using a mobile phone-based survey when cities and towns are under quarantine. Infect Control Hosp Epidemiol. 2020:1-5.

24. Reeves JJ, Hollandsworth HM, Torriani FJ, Taplitz R, Abeles S, TaiSeale $M$, et al. Rapid response to COVID-19: health informatics support for outbreak management in an academic health system. J Am Med Inform Assoc. 2020

25. Smith AC, Thomas E, Snoswell CL, Haydon H, Mehrotra A, Clemensen J, et al. Telehealth for global emergencies: Implications for coronavirus disease 2019 (COVID-19). J Telemed Telecare. 2020:1357633X20916567.

26. Szperka CL, Ailani J, Barmherzig R, Klein BC, Minen MT, Singh $\mathrm{RBH}$, et al. Migraine care in the era of COVID-19: Clinical pearls and plea to insurers. Headache. 2020.

27. Valsalan P, Baomar TAB, Baabood AHO. IOT BASED HEALTH MONITORING SYSTEM. J Crit Rev. 2019;7(4):2020.

28. Wang CJ, Ng CY, Brook RH. Response to COVID-19 in Taiwan: big data analytics, new technology, and proactive testing. JAMA 2020;323(14):1341-2.

29. Wind TR, Rijkeboer M, Andersson G, Riper H. The COVID-19 pandemic: The 'black swan'for mental health care and a turning point for e-health. Internet Interv. 2020

30. Wright JH, Caudill R. Remote treatment delivery in response to the COVID-19 pandemic. Psychother Psychosom. 2020;89(3):1.

31. Yang Y, Li W, Zhang Q, Zhang L, Cheung T, Xiang Y-T. Mental health services for older adults in China during the COVID-19 outbreak. Lancet Psychiatry. 2020;7(4):e19.

32. Yasaka TM, Lehrich BM, Sahyouni R. Peer-to-Peer contact tracing: development of a privacy-preserving smartphone app. JMIR mhealth uhealth. 2020;8(4):e18936.

33. Zhou X, Snoswell CL, Harding LE, Bambling M, Edirippulige S, Bai X, et al. The role of telehealth in reducing the mental health burden from COVID-19. Telemed J E Health. 2020;26(4):377-9.

34. Liu S, Yang L, Zhang C, Xiang YT, Liu Z, Hu S, et al. Online mental health services in China during the COVID-19 outbreak. Lancet Psychiatry. 2020;7(4):e17-e8.

35. Mian A, Khan S. Medical education during pandemics: a UK perspective. BMC Med. 2020;18(1):1-2.

36. Dashraath P, Jeslyn WJL, Karen LMX, Min LL, Sarah L, Biswas A, et al. Coronavirus disease 2019 (COVID-19) pandemic and pregnancy. Am J Obstet Gynecol. 2020.

37. Li Z, Ge J, Yang M, Feng J, Qiao M, Jiang R, et al. Vicarious traumatization in the general public, members, and non-members of medical teams aiding in COVID-19 control. Brain Behav Immun. 2020

38. Liu S, Luo P, Tang M, Hu Q, Polidoro JP, Sun S, et al. Providing pharmacy services during the coronavirus pandemic. Int J Clin Pharm. 2020.

39. Waters A. Telemedicine services thrive during Covid-19. Vet Rec. 2020;186(12):365.

40. Rogers LC, Lavery LA, Joseph WS, Armstrong DG. All Feet On Deck-The Role of Podiatry During the COVID-19 Pandemic: Preventing hospitalizations in an overburdened healthcare system, reducing amputation and death in people with diabetes. J Am Podiatr Med Assoc. 2020.

41. Jakhar D, Kaur I, Kaul S. Art of performing dermoscopy during the times of coronavirus disease (COVID-19): simple change in approach can save the day! J Eur Acad Dermatol Venereol. 2020.

42. Boulos MNK, Geraghty EM. Geographical tracking and mapping of coronavirus disease COVID-19/severe acute respiratory syndrome 
coronavirus 2 (SARS-CoV-2) epidemic and associated events around the world: how 21st century GIS technologies are supporting the global fight against outbreaks and epidemics. BioMed Central. 2020.

43. Ouzzani M, Hammady H, Fedorowicz Z, Elmagarmid A. Rayyan-a web and mobile app for systematic reviews. Syst Rev.2016;5(1):210.

44. Perrella A, Carannante N, Berretta M, Rinaldi M, Maturo N, Rinaldi L. Editorial-Novel Coronavirus 2019 (Sars-CoV2): a global emergency that needs new approaches. Eur Rev Med Pharmaco. 2020;24:2162-4.

45. Barbabella F, Melchiorre MG, Quattrini S, Papa R, Lamura G, Richardson E, et al. How can eHealth improve care for people with multimorbidity in Europe?: World Health Organization, Regional Office for Europe Copenhagen; 2017.

46. Fan J, Han F, Liu H. Challenges of big data analysis. Natl Sci Rev. 2014;1(2):293-314.

47. Stowe S, Harding S. Telecare, telehealth and telemedicine. Eur Geriatr Med. 2010;1(3):193-7.

48. Tuckson RV, Edmunds M, Hodgkins ML. Telehealth. N Engl J Med. 2017;377(16):1585-92.

49. Cucinotta D, Vanelli M. WHO declares COVID-19 a pandemic. Acta bio-medica: Acta Biomed. 2020;91(1):157-60.

50. Fadahunsi KP, Akinlua JT, O'Connor S, Wark PA, Gallagher J, Carroll $\mathrm{C}$, et al. Protocol for a systematic review and qualitative synthesis of information quality frameworks in eHealth. BMJ Open. 2019;9(3):e024722.

51. Shekelle PG, Morton SC, Keeler EB. Costs and benefits of health information technology. Evid Rep Technol Assess (Full Rep). 2006;132(April): 1-71

52. Hofmann P, Oesterle S, Rust P, Urbach N. Machine Learning Approaches along the Radiology Value Chain-Rethinking Value Propositions. Mach Learn. 2019;5:15-2019.

53. Ng M-Y, Lee EYP, Yang J, Yang F, Li X, Wang H, et al. Imaging profile of the COVID-19 infection: radiologic findings and literature review. Radiol Cardiothorac Imaging. 2020;2(1):e200034.

54. Vaishya R, Javaid M, Khan IH, Haleem A. Artificial Intelligence (AI) applications for COVID-19 pandemic. Diabetes Metab Syndr. 2020 . 